able in suitable circumstances for the reader, and especially the importance of high standards of education and professional ability on the part of the library staff.

These points were elaborated more fully later at the conference by Dr. L. W. Sharp in a paper entitled "What do we look for in a University Library ?" Dr. Sharp said little of library co-operation, believing it to be in a very healthy state so far as university libraries are concorned. He referred, however, to some of the difficulties occasioned by departmental libraries and made some suggestions for co-operation here in regard to book selection, exhibits and the like. Like Sir Philip Morris, he stressed the supreme importance of the quality of the library staff, referring to the importance of a university librarian having othor academic interests and of encouraging his assistants to widen their interests, for example, through exchanges of staff with other libraries at home and abroad and by the provision of more research scholarships for special library projects. On the subject of library design, he emphasized, like Sir Philip, the importance of having regard to individual circumstances, as well as to the needs of the reader, and commended specially the provision of some rooms for special collections. He stressed particularly the principle that the university library is equally for masters and scholars, and that students should have as free access as any other readers. He does not think that the division into a scholars' library and a masters' library, from which scholars are excluded, is sound; the aim should be to let the student feel that he is a member of a scholarly community and that he is welcome and his place is honourable.

Among the other papers presented to the conference, three were of particular interest to the scientist. They dealt with the general theme, "The Library in the Community", that of Mr. W. S. Haugh (city librarian, Bristol) reviewing the public library service in general. Mr. Haugh said that only fifteen English municipal authorities serving populations in excess of a hundred thousand exceeded $1 s, 6 d$. per head of population in their expenditure on books during 1952-53, whereas nine spent less than 10d. per head as against the $2 s$. suggested as standard in the centenary assessment brochure. For the counties later figures are available, and seven English county authorities are estimated to exceed 2s. per head in 1955-56 and seven others to be spending less than 1s. $3 d$. Of more specific interest to the scientific worker and technologist, however, were Mr. Haugh's observations on the importance of adequate expenditure on books in the schools and its bearing on educational efficiency, and what is being done by county libraries and other public library services to improve the facilities for educational reading for children as well as for students of technology and of other subjects. He referred particularly to some recent developments in the provision of technical information services by the public libraries, such as the scheme at Liverpool that provides for an immediate temporary technical library and a permanent technical library at a cost of $£ 270,000$; the establishment of technical library facilities at the Speke Branch Library serving the trading estate there, as well as branch technical libraries elsewhere; the extension of the Leeds commercial and technical library; the establishment of a separate technical department at Rugby; and the formation at Luton, where the central library maintains a large file of information on the requirements of the export trade, of the Luton and District Technical Information Service. He also mentioned the installation earlier this year in the Manchester Central Library of a teleprinter apparatus giving a direct link to more than a hundred users in the Manchester area, two thousand in the United Kingdom and twenty-five thousand in twenty-one centres abroad, and to the formation of co-operative industrial and commercial reference and information services among public libraries and business firms both in the West London and the North London areas.

Of the other two papers, Mr. H. Thompson (tech. nical librarian, Lancashire County Library), dealing with technical library services in the county, described more particularly the nature of this service, emphasizing its bearing on technical education, and the importance both of mobility and of taking full account of the various requirements of the groups served. Mr. D. J. Foskett (librarian and information officer of the Metal Box Co., Ltd.), dealing with special libraries, also referred to co-operation in the technical field, and his paper was particularly valuable for emphasizing the necessity in all such schemes of remembering that the special library owes its first responsibility to the group by which it is maintained. If this is ignored, the special library can scarcely make its contribution either in co-operation or in the development of new techniques and improved services.

\section{ROTHAMSTED EXPERIMENTAL STATION REPORT FOR 1954}

$\mathrm{W}^{\mathrm{r}}$ ITH the advent of any new agricultural problem that is amenable to scientific treatment, it has become almost a matter of course for the interested parties to ask: "What is Rothamsted doing about it ?" Clearly it is impossible for any research station to follow up too many of the problems of the moment without dangerous dispersal of effort and neglect of fundamental aspects. It is therefore heartening to see that the annual report of the Rothamsted Experimental Station (Pp. 242, 7s, 6d., from Rothamsted Experimental Station, Harpenden) again reflects a most satisfactory balance between pure and applied research and in the choice of the problems being studied. It is also clear from the very large number of visitors from all parts of the world that the Station continues to play a vital part in the exchange of information.

In the Physics Department there have been further advances in the techniques for measuring microclimates, and these methods are being used to study the conditions affecting the spread of virus diseases and of blight in potatoes. A new sodium-saturation test has been used to assess the increase in crumb cohesion caused by certain high polymers. It is interesting to note that some of these are more effective on acid than on calcareous soils. Work continues on the crystal structure of kaolinite.

Notable among a wide range of studies in the Chemistry Department are experiments on the placing of fertilizers. It has been demonstrated that some crops, including potatoes, benefit from the placing of nitrogen and potassium as well as phosphorus. Important progress has been made in the estimation of ammoniacal and nitrate nitrogen in soils, and fundamental studies are being made of 
mineral phosphates and of organic nitrogen and phosphorus compounds in soils.

The Pedology Department is closely linked with the Soil Survey and, in collaboration with the latter, a study has been made of the mineralogy of sand and clay fractions from a wide range of soils from Great Britain and the Colonial Territories. This work is providing important data on soil formation and classification. Progress is being made with the survey of trace-element distribution in British soils, and work continues on the effects of leaf leachates in soil-forming processes.

Investigations on the possibility of controlling disease fungi by antagonistic micro-organisms are in progress in the Soil Microbiology Department. It has now been shown that the action of Actinomycetes in suppressing the root fungus Helminthosporum is antibiotic and not merely competitive. Work continues on the strains of clover nodule bacteria which fail to produce effective nodules, and attempts are being made to select genetically stable strains for seed inoculation.

Studies in the Botany Department include the mutual interaction of iron and other micro-nutrients, the uptake of nutrients by plants through the leaves and by excised roots, and the physiological effects of virus infections. Work on kale has shown that there is an optimum leaf area, per unit area of land, for dry-matter production. If this is exceeded, efficiency falls off due to the mutual interference of leaves. Studies on weeds continue, with special attention being paid to wild oats.

The Biochemistry Department is mainly concerned with the study of representative enzyme systems, special attention being paid to the enzymes of bracken in the hope that measures of control may ultimately result. Various oxidation systems are also being studied, and progress has been made in designing a press for the large-scale extraction of protein from fresh leaves.

Work in the Plant Pathology Department seems to indicate that, in newly inoculated leaves, virus particles are continually synthesized and broken down and that the ratio of breakdown to synthesis increases with temperature. Among much other interesting work on virus diseases, it has been shown that the incidence of yellows in sugar beet is much reduced by systemic insecticides. Mycological studies have been carried out in relation to a number of crops, and the value of soaking sugar-beet seed in ethyl mercury phosphate has again been emphasized.

In the Nematology Department intensive study is being made of eelworms, their relationsh'ps to host plants and the conditions under which populations build up. Surveys at Rothamsted show that increases of eelworm cysts on plots under continuous mangolds and sugar beet have been very slight during the past eight years, but that the highest densities are associated with manurial treatments giving the highest yields.

Research has continued in the Insecticides Department on the mode of action of organo-phosphorus insecticides and, in particular, on their interaction with the esterase systerns of various insects. Useful work is reported on practical methods for controlling black aphis on beans and the wheat bulb fly, and progress has been made in rearing the latter in the laboratory.

The biology of the wheat bulb fly is also being studied in the Entomology Department. Work continues on the dispersal of aphids and on the biology of their natural enemies. Interesting studies of gall midges of various plants are reported, in particular the Hessian fly and the midges of white clover, the latter being especially important in relation to the production of clover seed.

The Bee Department once again presents a faseinating research report on foraging habits and social organization. It has been shown that the foraging of bees may be induced by the release in the hive of a scent which they have learnt to associate with food, and this may have great importance in problems of directing bees to particular crops. The sharing of sugary substances collected by one bee with the other members of a colony (using syrup containing carbon-14), the nature and functions of "queen substance' and trials of acaricides are among other studies reported.

An electronic computer has now been installed in the Statistics Department, and an intensive study is being made of its potentialities. The survey of hill and livestock-rearing farms is complete and will indicate what scope exists for further expenditure on upland farms. Surveys of fertilizer practice and rabbit damage continue.

The report closes with two useful review articles on "Clay Minerals" and on "The Uptake of Nutrients from Leaf Sprays by Agricultural Crops".

\section{EAST MALLING RESEARCH STATION REPORT FOR 1954}

$\mathrm{T}$

HE forty-second annual report, for 1954, of the East Malling Research Station, near Maidstone, Kent (170 pp., 12s. 6 d. post paid from the Station), includes two general papers of particular interest. The first is the text of the seventh Amos Memorial Lecture, by Prof. T. A. Bennet-Clark, who reviews various concepts of the mechanism by which water ascends large trees, showing that this is not yet fully understood, and makes a plea for more research on the matter. The second is by S. C. Pearce and D. W. P. Greenham, and is a history of the Station's land in the parish of East Malling. It has boen possible to trace certain land uses as far back as A.D. 1411, and such historical investigations might achieve useful correlation with modern soil survey.

Malling types of apple rootstocks are now famous, and H. M. Tydeman gives a most useful summary of the twenty-four types, and also crab $C$. His text is very short, but five tables and thirty-five excellent half-tone illustrations give very detailed information about winter and summer characters. D. W. Way, E. S. J. Hatcher and R. J. Garner have investigated the propagation of rootstocks by means of root cuttings. Position on the original root system, length, moisture relations, depth of planting, and various methods of coating the cut ends, have all been assessed, and detailed results are presented. The two last-mentioned workers have also experimented with propagation of Malling crab $C$, by sphæroblast cuttings. Sphæroblasts are rounded swellings on woody stems which are able to produce shoot budssufficient to yield some twenty-five hardwood cuttings per maiden tree. The peach variety Hale's Early is compatible with a Brompton rootstock, though not 